\title{
COTTUS GOBIO LINNAEUS, 1758 COMMUNITY INTEREST SPECIES CONSERVATION IN UPPER TÂRNAVA MARE RIVER BASIN, THROUGH FISH POPULATIONS REHABILITATION FOR BROWN TROUT ZONE BASED ON A DECISION-SUPPORT MANAGEMENT SYSTEM
}

\author{
Cristina, Cismaş ${ }^{1}$, Doru, Bănăduc ${ }^{2}$, Răzvan, Voicu ${ }^{3}$ and Angela, Curtean-Bănăduc ${ }^{4}$ \\ "Lucian Blaga" University of Sibiu, Faculty of Sciences, Sibiu, Romania, RO-550012, cristina.brumar@ulbsibiu.ro \\ 2"Lucian Blaga" University of Sibiu, Applied Ecology Research Centre, Sibiu, Romania, RO-550012, doru.banaduc@ulbsibiu.ro \\ ${ }^{3}$ National Institute of Hydrology and Water Management, Bucharest, Romania, RO-013686, rzvnvoicu@yahoo.com \\ 4"Lucian Blaga" University of Sibiu, Applied Ecology Research Centre, Sibiu, Romania, angela.banaduc@ulbsibiu.ro
}

\begin{abstract}
The ADONIS: CE software has been used for two fish species, Cottus gobio, of conservation interest and Salmo trutta fario, of economic interest, to design an on-site (upper Târnava Mare River) adapted support-system model for management decision-making. Habitat needs and indicators of favourable conservation status have been investigated, pressures and threats to these fish species have been determined, and management elements have been suggested. This management system allows the proper organization of management measures for the renaturation of the local natural fish associations in the local brown trout zone. KEY WORDS: Bullhead, brown trout, lotic systems, habitats, human impact, assessment, management.
\end{abstract}

\section{INTRODUCTION}

The water resources of the relatively high altitude Romanian Carpathians are typically of good quality where the effects of human activities are not significant (Mihăiescu et al., 2013; Breabăn et al., 2014; Romanescu, 2016).

Fish are one of the most conservative and economically valuable taxonomic groups/natural resources which are affected by a high variety of human impact (Năvodaru and Năstase, 2006; Gumpinger and Scheder, 2008; Bănăduc et al., 2011; Rumana et al., 2015; Lenhardt et al., 2016).

EU member countries gave their consent in 1992 for the Habitats Directive, in order to allow the species of European Community interest to thrive, in conformity with the obligation to conserve the species and habitats included in this Directive (Annex 2), by preserving or improving their ecological status (*, 1992).

This objective of this research was to design a model for a management tool for the main fish species in the studied lotic sector. In nature conservation, modeling is commonly used to get the "large image" of different systems and/or actions within specific areas. The elements of the modeling process assist in discriminating recognizable stages of species and their habitat management.

Using the ADONIS:CE free software, we can plan in details models that support the main needed management issues. The models mentioned focus on three main operational areas, valuable for environmental conservation: 1) to confirm the present ecological state, 2) to assess the results of the induced modifications, and 3) to suggest a program to enhance the present state in a necessary manner. Lastly, various diagrams can be generated to highlight the main elements of management. (Hall and Harmon, 2005)

\section{STUDY AREA, MATERIAL METHODS}

The lotic systems of the upper Târnava Mare River are situated in the inner zone of the Romanian Carpathians. With a water basin of 3,606 $\mathrm{km}^{2}$ and a length of $221 \mathrm{~km}$ (Badea et al., 1983), this river is one of the main lotic systems of Transylvania (Romania).

For the most representative and valuable fish species of the studied area, Salmo trutta fario species (Fig. 1) which is of economic interest, and Cottus gobio (Fig. 2) which is of conservation interest, individuals were sampled and/or identified in the catches of local fisherman in 2016. All these individuals were released quickly in situ after identification.

The status of the fish populations was evaluated based on criteria including: the size of fish populations; the size of the population range in the studied area; the equilibrated distribution of the captured individuals in age classes; and maximum and minimum numbers of individual fish species in fish communities. The habitat requirements, pressures and threats on Salmo trutta fario and on Cottus gobio were studied in connection with their ecological status, the connections between them and the conservation circumstances of these species.

An adaptable management model was designed to assemble a proper management plan that would definitively preserve the studied fish species that are present in the researched lotic ecosystems, with a highlight on necessary processes. The ADONIS: Community Edition (ADONIS:CE) free software, designed by the Business Object Consulting (BOC) Group, 5 
was used in this case. This software is in a convenient form of ADONIS with a few restraints (in comparison with the commercial version). It uses a Business Process Model and Notation (BPMN), a standardized modelling language which supports highlighting recognizable processes. ADONIS:CE is usually used as an access point to Business Process Management. These processes can be modelled using compatible notation. $(* *)$

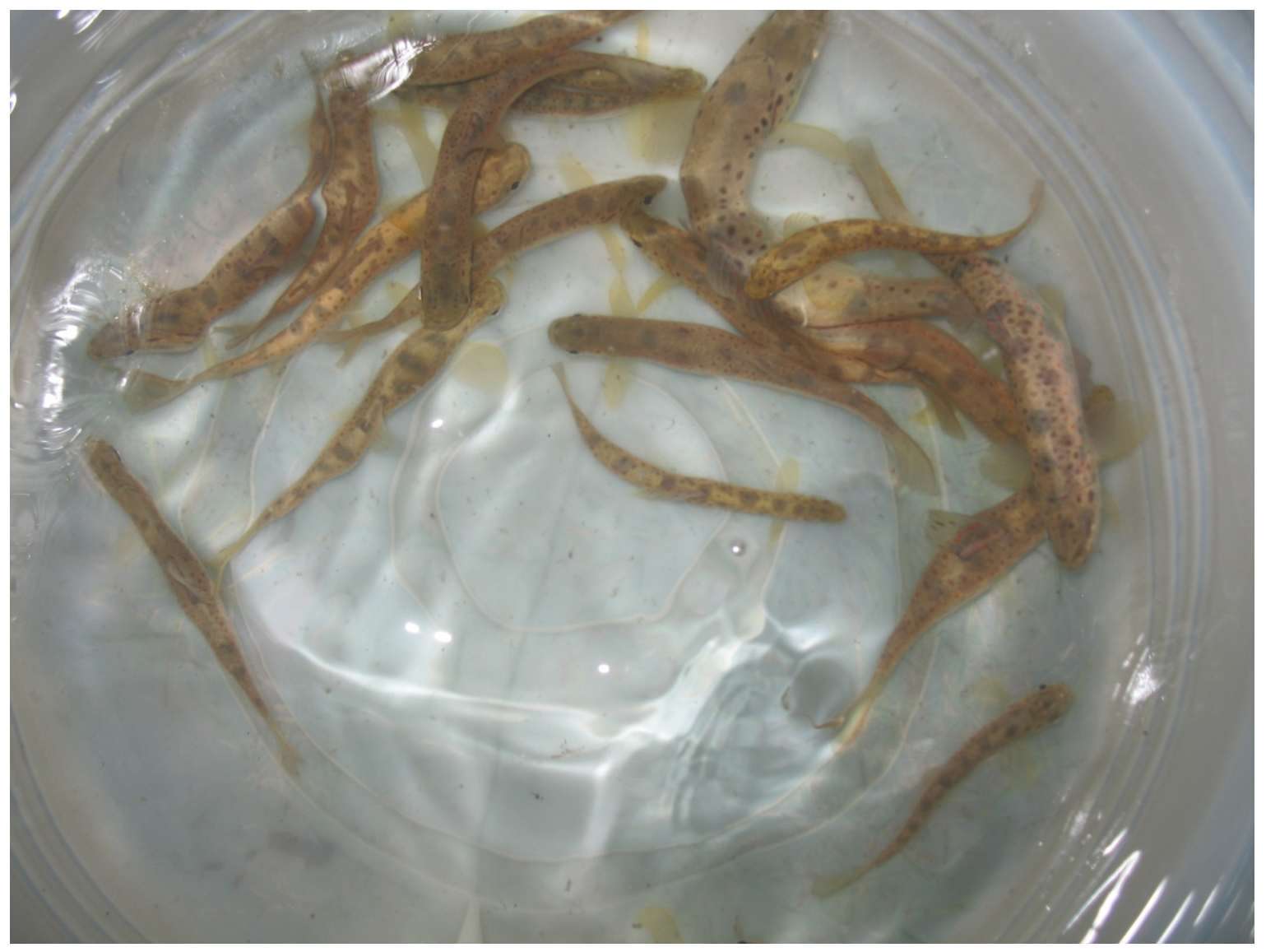

Figure 1. Salmo trutta fario.

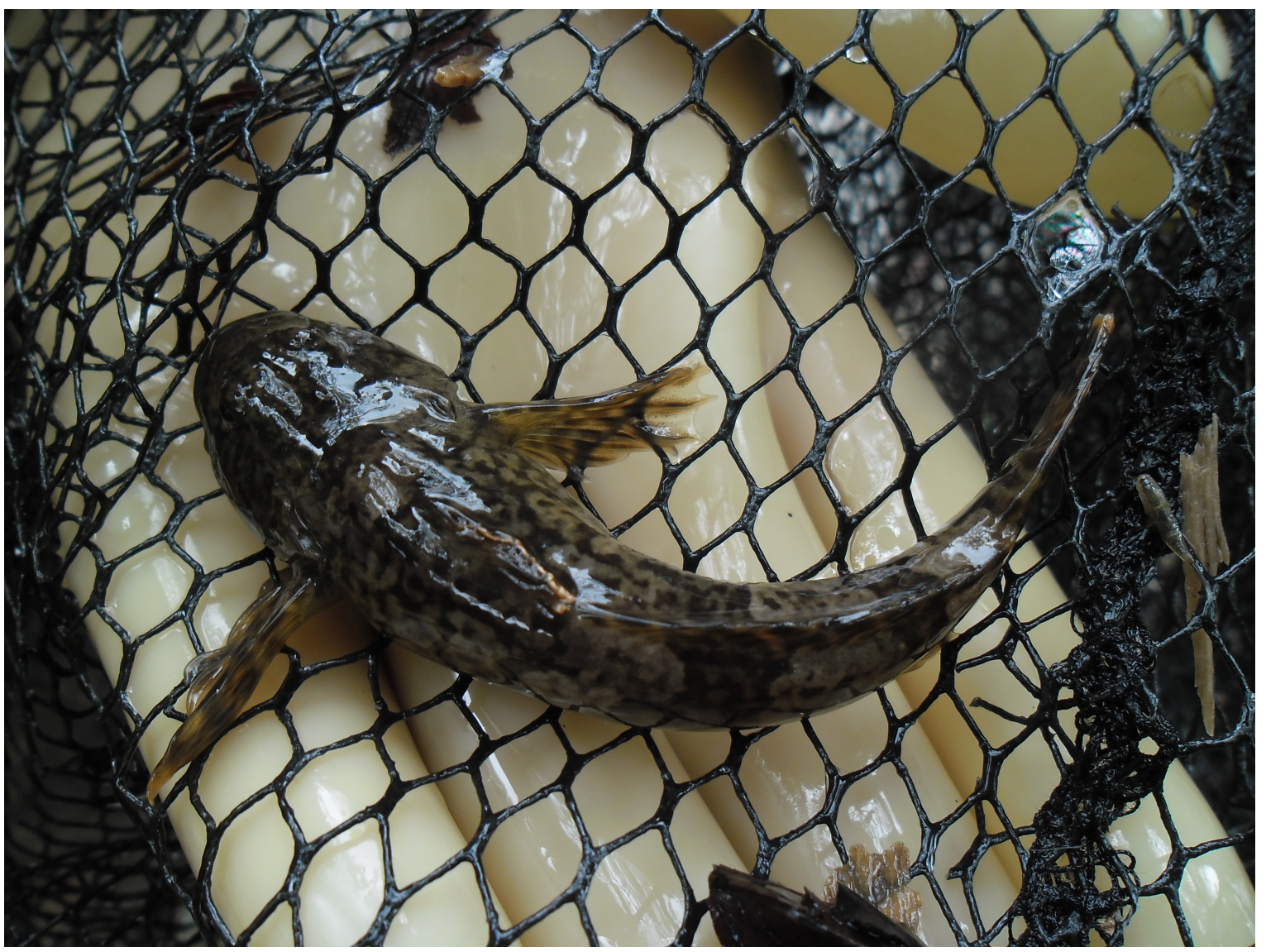

Figure 2. Cottus gobio. 


\section{RESULTS AND DISCUSSION}

Identified human pressures and threats. In the studied Târnava Mare River upstream sector, from its springs area to upstream Zetea Dam lake, based on the Biotic Integrity Index for Carpathian river assessment score values (Bănăduc and Curtean-Bănăduc, 2002) the local brown trout zone ecological state vary greatly here, reflected by scores variability from $45-$ excellent (score reflect an excellent, comparable to pristine conditions, exceptional assemblage of fishes) to 10 - poor (score describes very few species and individuals present, tolerant species dominant in some sectors).

Here, seven main pressures and threats on Salmo trutta fario and Cottus gobio fish species were found, as a synergic effect the natural fish associations of the trout lower zone were partially skewed or replaced by unnatural fish association (Bănărescu, 1964; Bănăduc, 2005) situation favoured by the human impact context. These main pressures and threats are: the characteristic habitat changes or damages, the river continuum fragmentation caused by the hydrotechnical constructions, the chaotic restockings, poaching, the water pollution, the deforestation of riparian vegetation, and the expansion of some invasive/more tolerant fish populations (Squalius cephalius, Gobo gobio, Barbus meridionalis, etc.), species that are competitors with Salmo trutta fario and Cottus gobio species characteristic for the brown trout zone, inducing the decreasing of the first species abundance and an accentuated decreasing of the second one.

Identified specific requirements. Both characteristic fish species for the brown trout zone need: a natural relatively high, debit variable, fast, cool and oxygenated water, with stones/rocky river bed and rapids, and heavy shadowed banks (Bănărescu, 1964; Bănărescu and Bănăduc, 2007). The basin lotic systems sectors connectivity, chaotic restocking, poaching and non-native species has highly negative impact.
Proposed specific habitat indicators. In the researched mountain lotic ecosystems, main habitat indicators are suggested here as justification for the presence or absence and relative abundance of Salmo trutta fario and Cottus gobio: relatively high water level (no less than $30 \mathrm{~cm}$ depth) (proportion $70 \%$ of the river), variable water flow (70\%), fast water speed $(90 \%)$, cool water temperature $(90 \%)$, oxigenated water $(90 \%)$, stones/rocky river beds and rapids $(90 \%)$, shadow banks $(90 \%)$. The basin lotic systems sectors connectivity $(100 \%)$, chaotic restocking $(0 \%)$, poaching $(0 \%)$, and nonnative species $(0 \%)$.

Management measures. With this proposed model we recommend that the most important management measures to be the followings: preservation of the natural hydrology, preservation of the natural morphology of the lotic system and its banks, no riverbed mineral exploitation should be allowed in the studied area, preserving the vegetation of the basin on the banks riverine valley slopes, a ban on the disposing of any type of waste in streams and rivers, keeping a permanent high/medium level of the water on rivers and streams especially in drought periods based on avoiding of significant water extractions, diminishing organic water pollution. All the hydrotechnical works should have fish pass facilities, the restocking should be strictly controlled from the scientific point of view, poaching should be totally banned, and the nonnative species should be eliminated through focused fishing.

\section{Adjusted model for the site management}

\section{Model description}

The model of the two fish species is structured in three processes (Fig. 3) to get an overview of the critical habitat requirements, of the possible indicators measured on the ground and of management measures for the rehabilitation of local natural fish associations in the local brown trout zone.

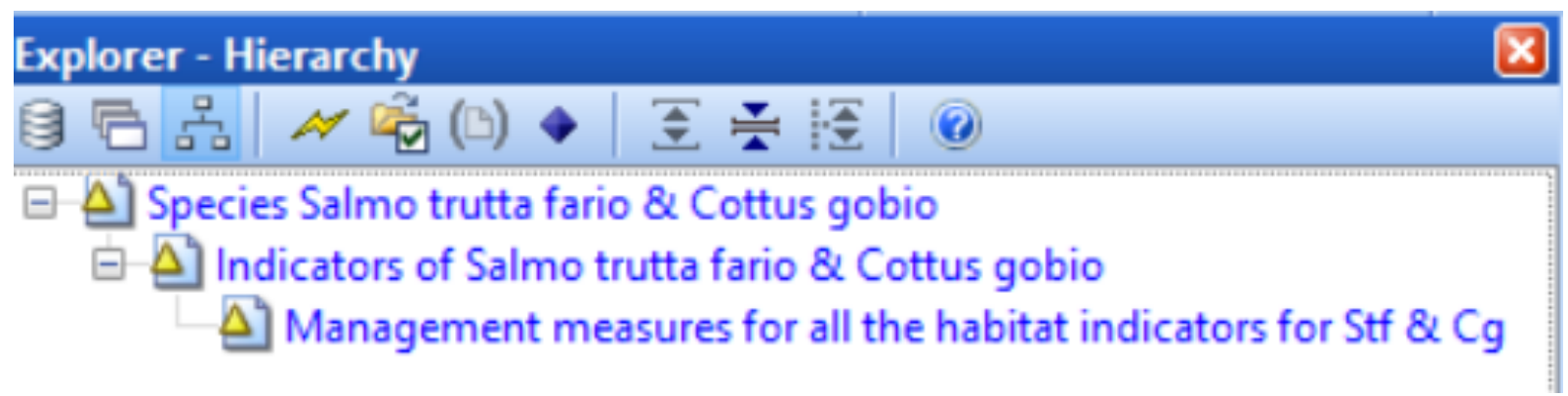

Figure 3. Processes hierarchy of the modelled species Salmo trutta fario and Cottus gobio.

The basic process (Fig. 4) begins with two activities describing the type of habitat and the critical habitat requirements (species needs to shelter, breeding, and feed). Then, with the help of a subprocess, the possible habitat indicators were structured (Fig. 5). It checks with a decision whether the conservation status is favorable or not. If conservation status is favorable ("Yes" branch, variable: "Favorable_conservation state"='YES', probability $53 \%$ ) then the process continues with the description of the pressures and threats of the two species and it ends. If the conservation status is not favorable ("No" branch, variable: "Favorable conservation state"='NO', probability $47 \%$ ), then the process returns to the "Specific Requirements" activity and revisits the "Habitat Indicators of the Salmo trutta fario and Cottus gobio" (Fig. 5) subprocess until the favorable conservation status is achieved. 


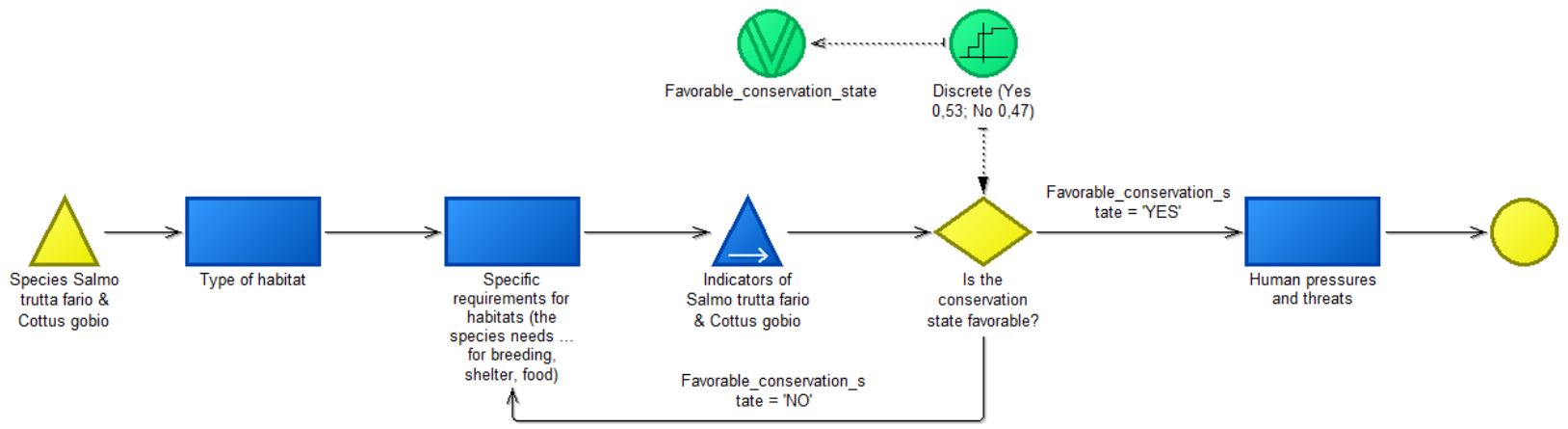

\section{Edit the model attributes to display your copyright info Powered by ADONIS Community Edition www. adonis-community.com}

Figure 4. Salmo trutta fario and Cottus gobio - main process.

The "Indicators of Salmo trutta fario and Cottus gobio" subprocess (Fig. 5) is structured in eleven decisions (each decision represents the habitat indicators of the two species), a subprocess that contains the management measures to be taken if the indicators are not in a favorable conservation status, follows the activity "Implementation of an integrated monitoring system" and the process ends. Each decision has associated a variable (the names of the indicators: high water level $-70 \%$ of the studied river sector, variable water flow $70 \%$, fast water speed $-90 \%$, cool water temperature - $90 \%$, oxigenated water - $90 \%$, stones/rocky river beds and rapids $90 \%$, shadow banks - 90\%, basin lotic systems sectors connectivity - $100 \%$, chaotic restocking - $0 \%$, poaching - $0 \%$, and non-native species - $0 \%$ ) and a random generator (presented above - which determines the percentage that the indicator ensures the favorable conservation status). For the first seven indicators, the difference between the actual and the favorable state is not as big as the last four indicators. If every decision is passed on the "YES" branch, then all the indicators go through to the last activity, namely "Implementation of an integrated monitoring system". If one of the indicators is not in favorable conservation status (e.g. for the third indicator, the "NO" branch, variable: "Natural_relatively_fast_speed_water_flow" = "NO", $10 \%$ probability) then go through the management measures in the subprocess "Management measures for all the habitat indicators for Salmo trutta fario and Cottus gobio" (Fig. 6) and returns to check again the indicator.

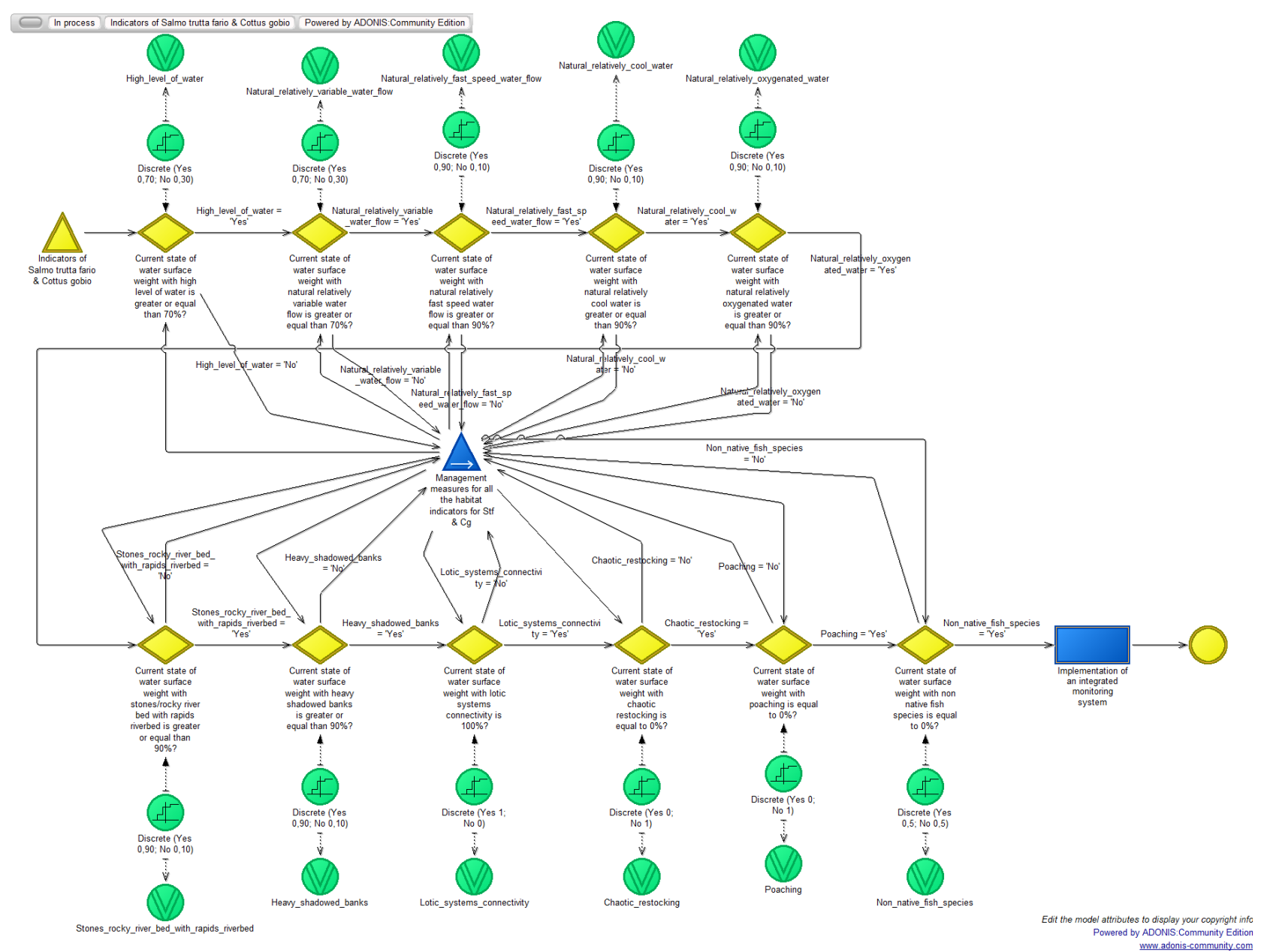

Figure 5. Salmo trutta fario and Cottus gobio - indicators. 
The "Management measures for all the habitat indicators for Salmo trutta fario and Cottus gobo" (Fig. 6) subprocess is structured in seven activities describing the management measures that need to be taken to bring the habitat indicators to favorable conservation status.
These measures are: preservation of the natural hydrology, no riverbed mineral exploitation should be allowed, preserving the vegetation of the basin, banning any type of waste disposal in streams and rivers, keeping a permanent high/medium level of the water, diminishing organic water pollution, hydrotechnical works should have fish pass facilities.

In process Management measures for all the habitat indicators for Stf \& $\mathrm{Cg}$ Powered by ADONIS:Community Edition

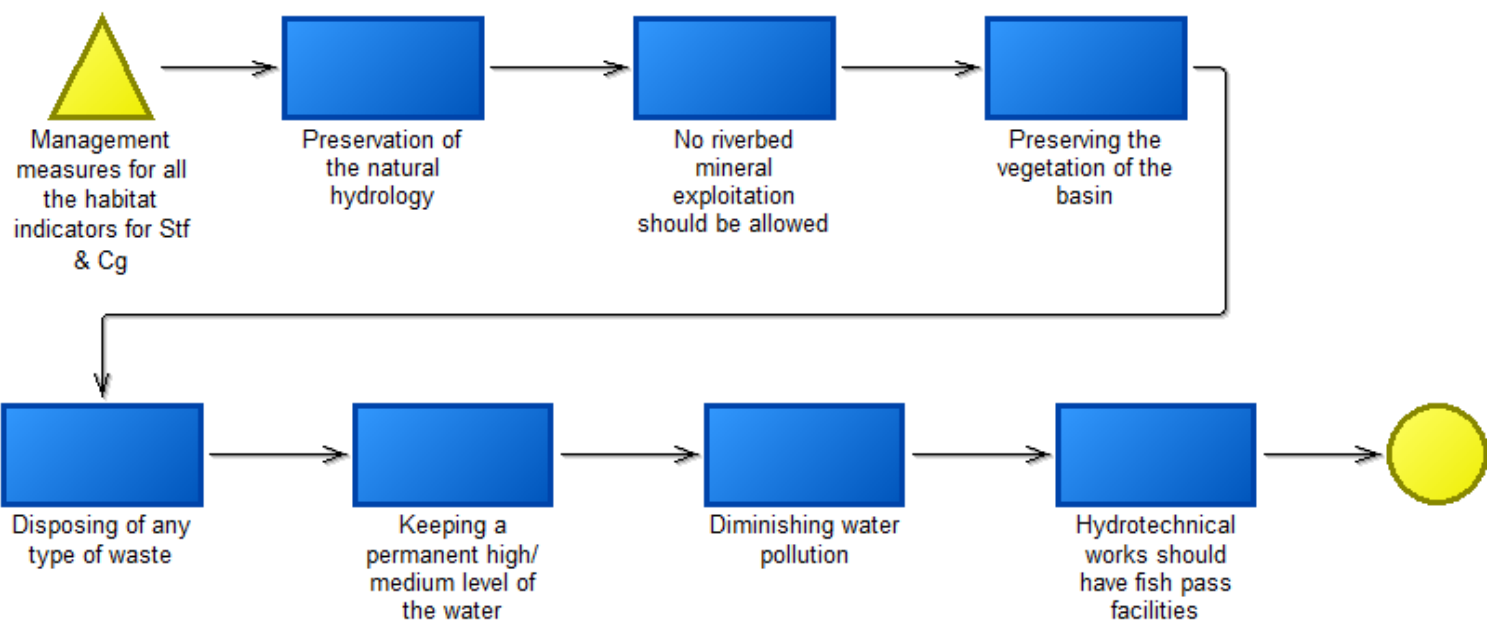

Edit the model attributes to display your copyright info Powered by ADONIS:Community Edition www. adonis-community.com

Figure 6. Management measures for all the habitat indicators for Salmo trutta fario and Cottus gobio.

\section{CONCLUSIONS}

In the present situation in which poaching, chaotic restocking and lotic systems fragmentation has obvious impact all over the year in the upper Târnava River basin, habitats should be properly managed as it was suggested by the proposed model. Critical for Cottus gobio and Salmo trutta fario species protection and conservation are: the characteristic habitat changes or damages, the river continuum fragmentation caused by the hydrotechnical constructions, the chaotic restocking, poaching, the organic water pollution, the deforestation of riparian vegetation, and the expansion of some invasive/more tolerant fish populations.

The ADONIS: CE software was used for the local natural fish species conservation, and we recommend a management model for Cottus gobio and Salmo trutta fario species that include its major ecological necessities regarding the habitat, the indicators that reveal a good ecological status - the optimum management measures to sidestep and/or remove the pressures and threats which adversely influence this fish species.

This specific on-site, on habitats and on fish species management decisions sustaining model plan for Cottus gobio and Salmon trutta fario, should be integrated in a management model for the Târnava River fish fauna.

\section{AKNOWLEDGEMENTS}

The authors wish to thank to Mr. Prof. Emil M. Popa for his valuable support in informatics, and to the numerous fishers operating in the Târnava River basin for their cooperation during the study. This research information was acquired in the study period for POS Mediu, priority ax 4 project code SMIS CSNR 17049 "Pentru Comunităţi Locale şi Natură - Bazele managementului integrat Natura 2000 în zona Hârtibaciu Târnava Mare - Olt (PH+ PRO MANAGEMENT Natura 2000)" and for Project ID 66243, SIDPOP - "Instrument suport pentru luarea deciziilor în domeniul managementului poluanţilor organici persistenţi. Studiu de caz: Bazinul hidrografic Mureş”, finanţat în cadrul programului R004 „Reducerea substanţelor periculoase, prin Mecanismul Financiar al Spaţiului Economic European (SEE).

\section{REFERENCES}

1. Badea, L., et al. (1983) Geografia României I, Editura Academiei Române.

2. Bănăduc D. (2005) Fish association - habitat quality relation in the Târnave Rivers (Transylvania, Romania) ecological assessment, Transylvanian Review of Systematical and Ecological Research, 2, 123-136.

3. Bănăduc D. (2011) New SCIS proposal regarding the ichtiofauna after the Alpine Biogeographic Seminar for Romania, Sibiu (Transylvania, Romania) 9-12 June 2008, Acta Oecologica Carpatica, 175-184, IV.

4. Bănărescu, P. M., (1964) Pisces-Osteichthyes, Fauna R. P. R., vol. XIII., Edit. Academiei R. P. R., Bucureşti, 962.

5. Bănărescu, P. M. and Bănăduc, D, (2007), Habitats Directive (92/43/EEC) fish species (Osteichthyes) on the Romanian Territory, Acta Ichtiologica Romanica, II: 4378.

6. Breabăn I. G. and Romanescu G. (2014) Status of water quality in Cuejdi hydrographic basin from Eastern Carpathian, Romania, Hydrology and Wather Resources, DOI: 10.5593/SGEM2014/S12.083, 639-646.

7. Gumpinger C. and Scheder C. (2008) Decline of biodiversity as a result of various impacts related to river 9 
regulation - exemplified by several small river catchments (Austria); Transylvanian Review of Systematical and Ecological Research 6, 141-148.

8. Hall C. and Harmon P. (2005) The Enterprise Architecture, Process Modeling and Simulation Tools Report, Version 1.1 (2005) November.

9. Lenhardt M., Jarić I., Kolarević S., Vuković-Gačić B., Knezević-Vukčević J., Smederevac-Lalić M., Cvijanović G. and Gačić Z. (2016) Impact of human activities on the status of the Danube River in Serbia: microbiological and ichthyofaunistic studies, Acta Oecologica Carpatica, IX, 151-176.

10. Mihăiescu T. C., Mihăiescu R., Vârban D. and Mihăiescu M. (2013) Water quality assessment of the Nadas River (Romania) in terms of NSF Water Quality Index, Annals of the Oradea University, Fascicle of Environment Protection, XXI, 651-656.
11. Năvodaru I. and Năstase A. (2006) Ichthyofauna of Danube River delta: Gorgova - Uzlina and Şontea Furtuna lakes complexes, Acta Ichtiologica Romanica, I, 185-202.

12. Romanescu G., Miftode D., Pintilie Mihu A., Stoleriu C. C. and Sandu I. (2016) Water quality analysis in mountain freshwater: Poiana Uzului Reservoir in the Eastern Carpathians, Chemistry Magazine, 1, 2318-2326.

13. Rumana H. S., Jeeva V. and Kumar S. (2015) Impact of the low head dam/barrage on fisheries - a case study of Giri River of Yamuna Basin (India), Transylvanian Review of Systematical and Ecological Research 17.2, $119-138$

14. * (1992) - http://ec.europa.eu/environment/water/waterframework/index en.html

15. ** - http://www.boc-group.com/products/adonis/bpmnmethod/ 